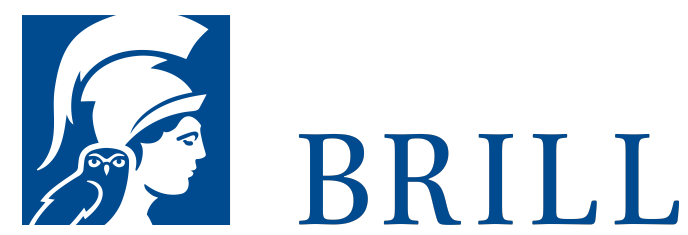

\section{Epistemische Rechtfertigung und Wahrheit als Empfehlung}

\section{Author: Gunnar Schumann}

Der Autor verfolgt das Ziel, zwei zentrale Begriffe der Erkenntnistheorie, den Begriff der epistemischen Rechtfertigung und den der Wahrheit, als normative Begriffe zu deuten. In Kontrast zur gängigen Auffassung in der zeitgenössischen Erkenntnistheorie soll gezeigt werden, dass beide Begriffe primär eine präskriptive und nur sekundär eine deskriptive Bedeutung haben, d.h. sie werden primär nicht zum Beschreiben, sondern zum epistemischen Empfehlen gebraucht. Eine moderate nicht-deskriptivistische Theorie, die sich eng an Richard Hares Metaethik anlehnt, wird so entwickelt und gegen verschiedene Einwände verteidigt. Aus der Normativität von Rechtfertigungs- und Wahrheitsbegriff werden zudem entscheidende Adäquatheitsbedingungen für substantielle Theorien beider Begriffe abgeleitet. Weder kann der Rechtfertigungsbegriff durch weitere normative Begriffe substantiell bestimmt noch naturalisiert werden. Die Struktur epistemischer Rechtfertigung ist weder kohärentistisch noch rein fundamentalistisch. Für den Wahrheitsbegriff ergibt sich, dass er, obwohl er keine primäre deskriptive Bedeutung hat, deswegen nicht semantisch redundant ist, wie deflationistische Wahrheitstheorien behaupten.

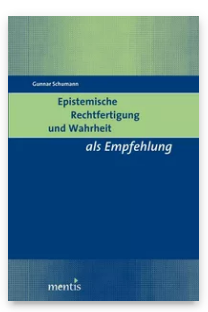

Pages: $35^{2}$

Seiten

Language:

German

Subjects:

General,

Philosophy

Publisher: Brill | mentis

E-Book (PDF)

Released online:

o1 Feb 2013

ISBN: 978-3-

89785-951-7

List price

Paperback

Publication date:

o1 Feb 2013

ISBN: 978-3-

89785-776-6

List price 
For more information see brill.com

Order information: Order online at brill.com +44330 333 0049 | customerservices@brill.com Submission information: brill.com/authors

Titles published by Brill | Fink, Brill | mentis or Brill | Schöningh: +49(o)715413279216| brill@brocom.de 